\title{
Densification Behaviour and Mechanical Properties of Aluminium Oxide and Cerium Oxide-Doped Yttria Tetragonal Zirconia Polycrystal Ceramics Using Two-Step Sintering
}

\author{
M. Golieskardi, M. Satgunam, and D. Ragurajan \\ Ceramics Technology Laboratory, Universiti Tenaga Nasional, 43000 Kajang, Selangor, Malaysia \\ Correspondence should be addressed to M. Golieskardi; mohsen_golieskardi@yahoo.com
}

Received 16 June 2014; Revised 30 October 2014; Accepted 30 October 2014; Published 13 November 2014

Academic Editor: Liqiang Jing

Copyright (c) 2014 M. Golieskardi et al. This is an open access article distributed under the Creative Commons Attribution License, which permits unrestricted use, distribution, and reproduction in any medium, provided the original work is properly cited.

\begin{abstract}
The densification behaviour, mechanical properties, and microstructure of high-purity $\mathrm{Al}_{2} \mathrm{O}_{3}$ and $\mathrm{CeO}_{2}$-doped Y-TZP with different weight percentage varied from 0.3 to $1 \mathrm{wt} \%$ were investigated. The samples were pressed uniaxially at $200 \mathrm{MPa}$ into rectangular bars and discs and pressureless-sintered at temperature ranging between $1250^{\circ} \mathrm{C}$ and $1450^{\circ} \mathrm{C}$ for $2 \mathrm{~h}$ while the microstructure was characterized with a scanning electron microscope (SEM). Two-step sintering process works well for temperature higher than $1400^{\circ} \mathrm{C}$ and it created most tetragonal phase arrangement for stable structure to delay ageing through phase transformation. The mechanical properties in terms of bulk density, Young's modulus, Vickers hardness, and fracture toughness were also measured. The results indicate that the addition of dopants accelerated the densification parameters and reinforced and toughened the obtained bodies. The maximum values for the mechanical properties of the $\mathrm{Al}_{2} \mathrm{O}_{3}$ and $\mathrm{CeO}_{2}$-doped Y-TZP ceramics were 6.01, 220 GPa, 13.8 GPa, and $7 \mathrm{MPa}$ for density, Young's modulus, Vickers hardness, and fracture toughness, respectively, which are higher than those of the doped samples.
\end{abstract}

\section{Introduction}

Yttria-stabilised tetragonal zirconia polycrystalline ceramics (Y-TZP) are becoming popular engineering materials due to their excellent mechanical properties, studied and used in many engineering applications, such as engine parts, valves, cutting tools, and moulds, due to their good fracture toughness, high strength, elastic modulus, and wear resistance [1-3].

In recent years, yttria-tetragonal zirconia polycrystals (Y-TZP), with their superior combination of mechanical properties and chemical inertness, have been employed in the biomedical field as an implant material [4-9]. In general, when a restricted number of $\mathrm{ZrO}_{2}$ particles undergo the transformation during cooling from the sintering temperature, the accompanying volume expansion would cause the development of a fine distribution of microcracks in the ceramic matrix. These microcracks would increase the toughness by interacting with a propagating crack, causing deflection and blunting of the crack. Due to this nature, the engineering application of pure $\mathrm{ZrO}_{2}$ proves to be nonviable as the sintered body would crumble to pieces upon cooling from the sintering temperature $[10,11]$.

To overcome this undesirable phase transformation, stabilisers such as magnesia $(\mathrm{MgO})$, calcia $(\mathrm{CaO})$, ceria $\left(\mathrm{CeO}_{2}\right)$, and yttria $\left(\mathrm{Y}_{2} \mathrm{O}_{3}\right)$ have been added in various quantities in zirconia. In general, alloying zirconia with these oxides reduces the change of chemical free energy, which in turn lowers the tetragonal to monoclinic transformation temperature to below ambient temperature [12-16]. Garvie et al. [17] highlighted the potential of increasing both the strength and toughness of zirconia through a mechanism involving the phase transformation of metastable tetragonal particles induced by the presence of the stress field ahead of a crack.

Kobayashi et al. [18] first discovered a serious limitation of Y-TZP ceramics for applications near $250^{\circ} \mathrm{C}$ in moist environment. Results revealed that the ceramic can suffer a slow, tetragonal to monoclinic phase transformation at the samples surface in a humid atmosphere, followed by microcracking and a serious loss in strength, a phenomenon 
subsequently known as ageing or low temperature degradation (LTD). Ever since then, many researchers have experimented with Y-TZP with an attempt to understand the basic micro mechanisms of the ageing-induced $(t)$ to $(m)$ phase transformation and to suppress this LTD phenomenon [1924]. Although the experimental observations of the ageing phenomenon are well understood, the actual mechanism responsible for the degradation has not been unequivocally explained. The effect of copper oxide $(\mathrm{CuO})$ doping Y-TZP has been studied by Kanellopoulos and Gill [25-27]. It was found that mechanism involving liquid phase enhanced due to the low melting point of $\mathrm{CuO}$ in $\mathrm{ZrO}_{2}$ matrix densification of the ceramics. The effect of TSS on the densification and grain growth of nanocrystalline 3Y-TZP ceramic was investigated by Mazaheri et al. [28]. From the results it was found that the grain growth rate of nanocrystalline 3Y-TZP in conventional sintering route is significantly lower than that of other ceramics such as $\mathrm{ZnO}$ and $\mathrm{Al}_{2} \mathrm{O}_{3}$; also full stabilized tetragonal zirconia ( $3 \mathrm{Y}-\mathrm{TZP}$ ) ceramic can be obtained at grain size $<275 \mathrm{~nm}$.

It has been reported that improved Y-TZPs with optimized mechanical properties and ageing resistant could be obtained by the addition of more than one stabiliser to zirconia. For instance, $\mathrm{Xu}$ et al. [29]. It was found that the addition of $\mathrm{CeO}_{2}$ to Y-TZP could prevent ageing, while retaining relatively high fracture toughness of 7-9 $\mathrm{MPam}^{1 / 2}$. Similar observation was made by Sato et al. $[30,31]$ who found that the ageing kinetics of 2, 3, and 4 mol\% Y-TZP sintered at $1400^{\circ} \mathrm{C}$ to $1650^{\circ} \mathrm{C}$ decreased with increasing yttria content. Results also showed that increasing yttria content resulted in a reduction in the onset critical ageing temperature for phase transformation.

\section{Materials and Method}

The experiment was conducted from a starting Y-TZP powder containing $3 \mathrm{~mol} \%$ yttria and cerium oxide-aluminium oxide powders of $99.9 \%$ purity as dopants manufactured by Kyoritsu Ltd., Japan. Three different compositions of $\mathrm{CeO}_{2}$ $\mathrm{Al}_{2} \mathrm{O}_{3}$-doped Y-TZP powder mixtures $(0.3,0.5$, and $1 \mathrm{wt} \%)$ and undoped Y-TZP sample were prepared. The ratio dopant to Y-TZP was 1:99, whereby, regardless of the percentage of dopant in each composition, the addition of both dopants will always be equal to $1 \mathrm{wt} \%$. Each powder was weighed carefully and then underwent an ultrasonification process, whereby the base powder (Y-TZP) is first added with $150 \mathrm{~mL}$ of ethanol and left for 6 minutes, followed by the addition of the two dopants $\left(\mathrm{Al}_{2} \mathrm{O}_{3}\right.$ and $\left.\mathrm{CeO}_{2}\right)$, and further ultrasonification of 22 minutes follows. The powder was composed of primary particles with an average size of $\sim 30 \mathrm{~nm}$ (Figure 1(a)) and spherical granules (Figure 1(b)). The powder was uniaxially compact in a standard procedure [32] at about $1 \mathrm{KN}$ using hardened steel mold and die assembly. The powder was processed by cold isostatic pressing at $200 \mathrm{MPa}$, followed by pressureless sintering at temperature ranging from $1250^{\circ} \mathrm{C}$ to $1450^{\circ} \mathrm{C}$ in air. Unlike regular pressureless sintering, twostep sintering involves increasing the temperature to about $1000^{\circ} \mathrm{C}$ and is maintained for a period of one hour, before further heating to $1250^{\circ} \mathrm{C}$. The sintered samples were ground on one face by Silicon Carbide, SiC papers of 120, 240, 600, 800 , and 1200 grades successively, followed by polishing with $6 \mu \mathrm{m}$ and $1 \mu \mathrm{m}$ diamond paste to produce an optical reflective surface. The Vickers indentation test performed using a load of $10 \mathrm{kn}$ on polished surfaces in order to measure the hardness and indentation toughness. Bulk density of the specimens was determined by the Archimedes method using distilled water. The Young's modulus of the sample can be calculated using the standard test method (ASTM E1876-97) [33-35]. The microstructure of the samples was examined by JSM- 6310 scanning electron microscopy (SEM).

\section{Experimental Results and Discussion}

3.1. Bulk Density. The variation of bulk density for Y-TZPs with different amounts of $\mathrm{Al}_{2} \mathrm{O}_{3}$ and $\mathrm{CeO}_{2}$ sintered at temperatures $1250^{\circ} \mathrm{C}-1450^{\circ} \mathrm{C}$ is shown in Figure 2. All YTZP compositions including the undoped shared a common trend. Addition of $\mathrm{Al}_{2} \mathrm{O}_{3}$ and $\mathrm{CeO}_{2}$ were found to be most beneficial at sintering temperatures of $1250^{\circ} \mathrm{C}$ to $1400^{\circ} \mathrm{C}$. The results for undoped Y-TZP at low sintering temperature $1300^{\circ} \mathrm{C}$ shows that the relative density achieved was below $95 \%$. In the case of the $0.5 \mathrm{wt} \% \mathrm{Al}_{2} \mathrm{O}_{3}$ and $\mathrm{CeO}_{2}$-doped ceramics, the two-step sintering at $1400^{\circ} \mathrm{C}$ was found to be beneficial in enhancing the densification of the ceramics. From the sintering regime employed, $1400^{\circ} \mathrm{C}$ was found to be the optimum sintering temperature as all Y-TZPs sintered at this temperature recorded densities that were close to $98 \%$. In addition, for the $0.5 \mathrm{wt} \% \mathrm{Al}_{2} \mathrm{O}_{3}$ and $\mathrm{CeO}_{2}$ doped Y-TZP, maximum density of $6.01 \mathrm{Mgm}^{-3}$ (i.e., $8 \%$ T.D.) was recorded at this temperature and further increase in the sintering temperature resulted in the decline of its bulk density. This phenomenon is probably attributed to a phase transformation from tetragonal to monoclinic zirconia that starts after $1400^{\circ} \mathrm{C}$. During the phase transformation, a volume expansion of zirconia grains (i.e., expansion of the zirconia lattice) occurs and therefore a significant decrease in density is reported. Similar results have been reported by other researchers working on $\mathrm{Al}_{2} \mathrm{O}_{3}$ or $\mathrm{CeO}_{2}$ as a sintering additive in Y-TZP $[36,37]$.

3.2. Young's Modulus. The effect of aluminium oxide and cerium oxide doped Y-TZP on the Young's modulus is shown in Figure 3. The addition of $\mathrm{Al}_{2} \mathrm{O}_{3}$ and $\mathrm{CeO}_{2}$ was beneficial in enhancing the elastic modulus of Y-TZP, especially at low sintering temperatures of $1250^{\circ} \mathrm{C}$ and $1300^{\circ} \mathrm{C}$ when compared to the undoped Y-TZP.

Figure 3 shows that an $E$ value of above $200 \mathrm{GPa}$ could be achieved with the additions of $\geq 0.5 \mathrm{wt} \% \mathrm{Al}_{2} \mathrm{O}_{3}$ and $\mathrm{CeO}_{2}$ when sintered at $1350^{\circ} \mathrm{C}$ as compared to $197 \mathrm{GPa}$ for the undoped Y-TZP. In comparison, the Young's modulus of the undoped Y-TZP started low, at $178 \mathrm{GPa}$ when sintered at $1250^{\circ} \mathrm{C}$; however, it soon increases with increasing sintering to reach a maximum of $202 \mathrm{GPa}$ when sintered at $1400-$ $1450^{\circ} \mathrm{C}$. Both the additions of 0.5 and $0.1 \mathrm{wt} \% \mathrm{Al}_{2} \mathrm{O}_{3}$ and $\mathrm{CeO}_{2}$ exhibited the highest modulus (209-220 GPa) when 


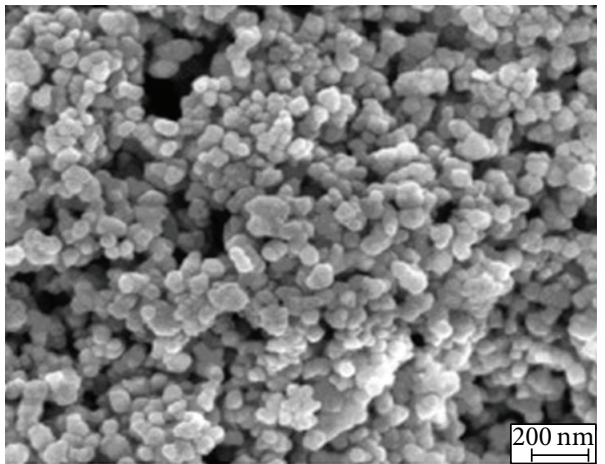

(a)

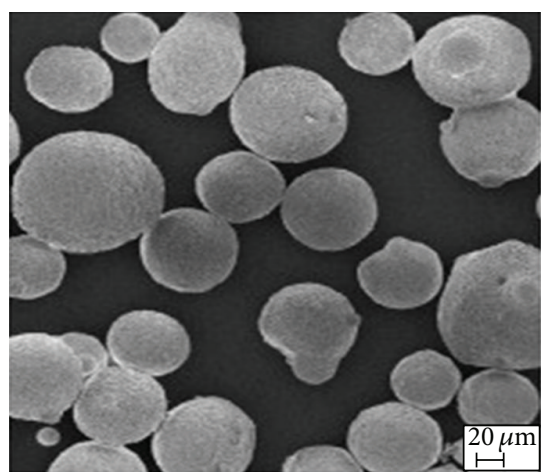

(b)

FIGURE 1: SEM micrographs show the particle morphology of Y-TZP: (a) primary particles; (b) spray-dried granules.

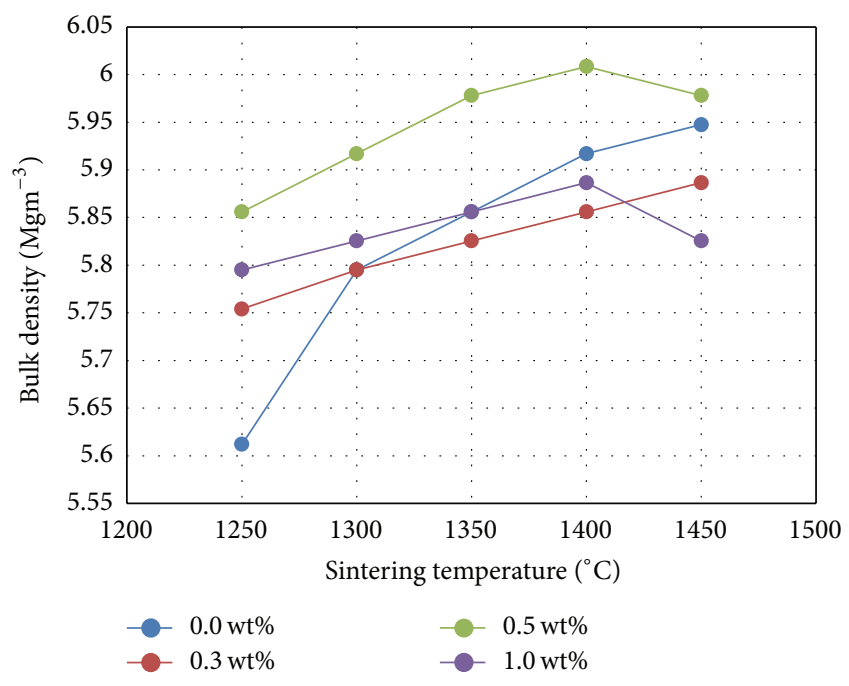

FIGURE 2: Effect of sintering temperature and sintering additives on the bulk density of Y-TZP.

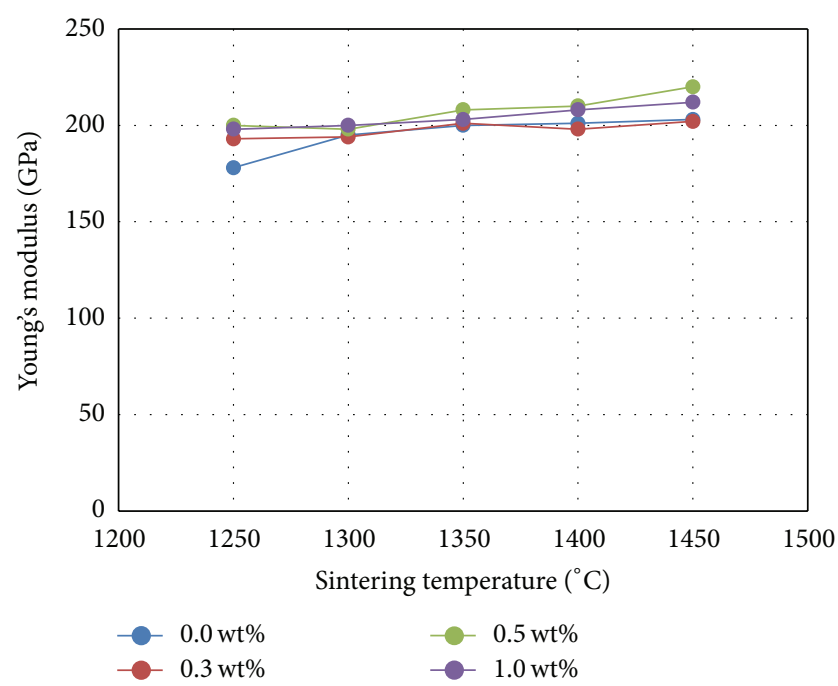

FIGURE 3: Effect of sintering temperature and sintering additives on the Young's modulus of Y-TZP.

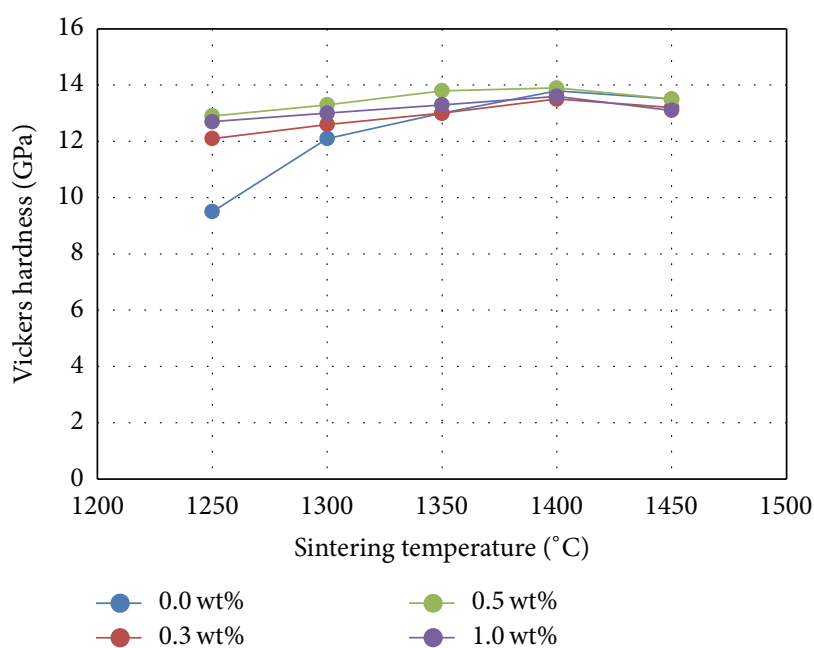

FIGURE 4: Vickers hardness variation of undoped and doped $\mathrm{Al}_{2} \mathrm{O}_{3}$ and $\mathrm{CeO}_{2}$-doped Y-TZP.

sintered at $1400^{\circ} \mathrm{C}$. Thereafter, the $E$ values of these ceramics fluctuated slightly with increasing temperature.

3.3. Vickers Hardness. The effect of sintering temperature and $\mathrm{Al}_{2} \mathrm{O}_{3}$ and $\mathrm{CeO}_{2}$ on the Vickers hardness of Y-TZP is shown in Figure 4. The results obtained in the present work confirmed that the $\mathrm{Al}_{2} \mathrm{O}_{3}$ and $\mathrm{CeO}_{2}$ additions were beneficial in improving the hardness of zirconia when sintered at low sintering temperatures.

However, in the present work, bulk density is unlikely to be the governing factor for the decline of hardness observed from $1400^{\circ} \mathrm{C}$ to $1450^{\circ} \mathrm{C}$ because all Y-TZPs except for the $0.5 \mathrm{wt} \% \mathrm{Al}_{2} \mathrm{O}_{3}$ and $\mathrm{CeO}_{2}$-doped Y-TZP were more than $97 \%$ dense at these temperatures as shown in Figure 2. The decline of hardness could possibly be due to grain growth resulting from sintering at higher temperatures. The $1 \mathrm{wt} \% \mathrm{Al}_{2} \mathrm{O}_{3}$ and $\mathrm{CeO}_{2}$-doped Y-TZP display the lowest hardness for sintering above $1400^{\circ} \mathrm{C}$ as shown in Figure 4 . Two possible explanations can be made for the decline in hardness of this sample when sintered above $1400^{\circ} \mathrm{C}$; firstly, hardness was strongly 


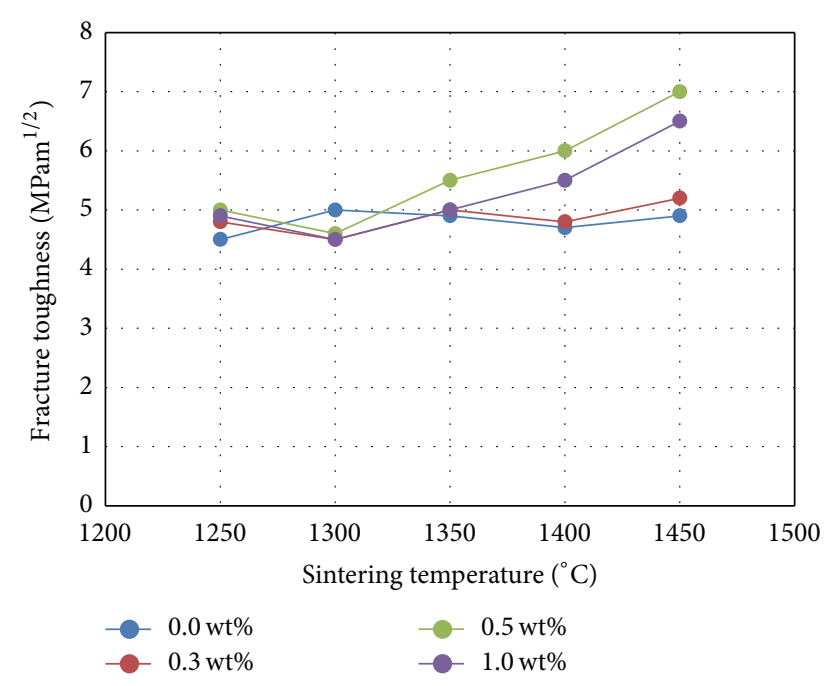

FIgURE 5: Variation of sintering temperature and $\mathrm{Al}_{2} \mathrm{O}_{3}$ and $\mathrm{CeO}_{2}$ addition on the fracture toughness of sintered Y-TZP.

dependent on bulk density, which decreased considerably during the temperature range as shown in Figure 2 and, secondly, it can be associated with the reduction of tetragonal phase content and a concomitant increased in the cubic phase formation in the zirconia matrix with increasing temperature. The reduction of tetragonal phase content had been cited by Lawson et al. [38] and Liu and Chen [39] to be the reason for the lower hardness of Y-TZP doped with $\mathrm{CuO}$ and $\mathrm{Sr}_{2} \mathrm{Nb}_{2} \mathrm{O}_{7}$, respectively.

3.4. Fracture Toughness. The effect of $\mathrm{Al}_{2} \mathrm{O}_{3}$ and $\mathrm{CeO}_{2}$-doped Y-TZP and sintering temperature on the fracture toughness $\left(K_{\mathrm{Ic}}\right)$ is shown in Figure 5. In general, additions of up to 0.3 wt $\% \mathrm{Al}_{2} \mathrm{O}_{3}$ and $\mathrm{CeO}_{2}$ have negligible effect on the fracture toughness of Y-TZP for the entire sintering temperature investigated. The fracture toughness of these samples was found to fluctuate between 4.5 $\mathrm{MPam}^{1 / 2}$ and $5.18 \mathrm{MPam}^{1 / 2}$. The fact that the $K_{\mathrm{Ic}}$ did not change significantly indicates that the additions of $\mathrm{Al}_{2} \mathrm{O}_{3}$ and $\mathrm{CeO}_{2}$ below $0.3 \mathrm{wt} \%$ did not affect the tetragonal phase stability of Y-TZP. Higher $\mathrm{Al}_{2} \mathrm{O}_{3}$ and $\mathrm{CeO}_{2}$ additions of 0.5 and $1 \mathrm{wt} \%$ also showed similar trend at sintering temperatures below $1300^{\circ} \mathrm{C}$. However, sintering above $1300^{\circ} \mathrm{C}$, the $K_{\text {Ic }}$ of both $\mathrm{Al}_{2} \mathrm{O}_{3}$ and $\mathrm{CeO}_{2}$-doped Y-TZP increased by increasing the temperature. This observation was more pronounced for the $0.5 \mathrm{wt} \% \mathrm{Al}_{2} \mathrm{O}_{3}$ and $\mathrm{CeO}_{2}$ doped Y-TZP, which exhibited a significant increase in $K_{\text {Ic }}$ from $4.6 \mathrm{MPam}^{1 / 2}$ at $1300^{\circ} \mathrm{C}$ to $7.0 \mathrm{MPam}^{1 / 2}$ at $1450^{\circ} \mathrm{C}$.

3.5. Microstructural and Phase Development. Scanning electron microscopic images of $0.5 \mathrm{wt} \% \mathrm{Al}_{2} \mathrm{O}_{3}$ and $\mathrm{CeO}_{2}$-doped Y-TZP sintered at $1450^{\circ} \mathrm{C}$ are presented in Figure 6(a). The analyses revealed that samples sintered at $1450^{\circ} \mathrm{C}$ showed particles that are nonspherical in shape and with little agglomeration and porosity. The surface topographies confirmed the presence of little agglomeration and porosity. For all of them, the zirconia appears agglomerated in light contrast and the aluminium oxide and cerium oxide appear as dark background particles. The average particle size obtained from the particle size distribution analysis using the grain intercept method was $1.13 \mu \mathrm{m}$.

The SEM results are in good agreement with the density of the $0.5 \mathrm{wt} \% \mathrm{Al}_{2} \mathrm{O}_{3}$ and $\mathrm{CeO}_{2}$-doped Y-TZP sintered at $1450^{\circ} \mathrm{C}$.

On the other hand, relatively rough surfaces were observed on surface sintered at $1250^{\circ} \mathrm{C}$ but no grains structures were clearly observed as depicted in Figure 6(b). The likely reason that $0.5 \mathrm{wt} \% \mathrm{Al}_{2} \mathrm{O}_{3}$ and $\mathrm{CeO}_{2}$-doped Y-TZP sintered at $1250^{\circ} \mathrm{C}$ did not have grain structure could be due to the presence of a glassy phase that suppressed the crystal growth and sealed the grain boundary.

It was also found that $1 \mathrm{wt} \% \mathrm{Al}_{2} \mathrm{O}_{3}$ and $\mathrm{CeO}_{2}$-doped $\mathrm{Y}$ TZP sintered at $1450^{\circ} \mathrm{C}$ resulted in severe phase transformation which was also accompanied by networks of micro- and macrocracks on the surface as typically shown in Figure 7.

High angle XRD analysis performed on the $1450^{\circ} \mathrm{C}$ sintered sample revealed that very high percentage of cubic phase (up to $48 \%$ ) was calculated in the zirconia matrix. This result indicated that sintering of $1 \mathrm{wt} \% \mathrm{Al}_{2} \mathrm{O}_{3}$ and $\mathrm{CeO}_{2}$-doped Y-TZP at $1450^{\circ} \mathrm{C}$ resulted in the formation of monoclinic and cubic phases in the zirconia matrix. The spontaneous phase transformation upon cooling from sintering and the development of the cubic phase was not observed for the $0.5 \mathrm{wt} \% \mathrm{Al}_{2} \mathrm{O}_{3}$ and $\mathrm{CeO}_{2}$-doped when sintered at $1450^{\circ} \mathrm{C}$.

\section{Conclusion}

Sinterability and mechanical properties of $\mathrm{Al}_{2} \mathrm{O}_{3}$ and $\mathrm{CeO}_{2}$ doped Y-TZP ceramics were studied in the present work. The beneficial effect of $\mathrm{Al}_{2} \mathrm{O}_{3}$ and $\mathrm{CeO}_{2}$ in enhancing the densification of Y-TZP has been revealed. The $\mathrm{Al}_{2} \mathrm{O}_{3}$ and $\mathrm{CeO}_{2}$-doped Y-TZPs achieved almost full density $(>97 \%$ of theoretical density) at $1300^{\circ} \mathrm{C}$. The study revealed that $1350^{\circ} \mathrm{C}$ was the optimum sintering temperature for all Y-TZPs to achieve $>98 \%$ of theoretical density.

The variation of Young's modulus with sintering temperature of all composition studied was in good agreement with the variation in bulk density. In general, it was found that $\mathrm{Y}$ TZPs containing above $0.5 \mathrm{wt} \% \mathrm{Al}_{2} \mathrm{O}_{3}$ and $\mathrm{CeO}_{2}$ attained $E$ values above $200 \mathrm{GPa}$ when sintered at temperature $1350^{\circ} \mathrm{C}$.

In general, the hardness of all $\mathrm{Al}_{2} \mathrm{O}_{3}$ and $\mathrm{CeO}_{2}$-doped $\mathrm{Y}$ TZPs was higher than the undoped material when sintered at $1250^{\circ} \mathrm{C}$ and $1300^{\circ} \mathrm{C}$. In particular, the addition of $0.3-1 \mathrm{wt} \%$ $\mathrm{Al}_{2} \mathrm{O}_{3}$ and $\mathrm{CeO}_{2}$ was most effective in enhancing the hardness of Y-TZP. These doped samples exhibited hardness of $>13 \mathrm{GPa}$ as compared to $\sim 9.7 \mathrm{GPa}$ for the undoped ceramics sintered at $1250^{\circ} \mathrm{C}$.

The additions of up to $0.3 \mathrm{wt} \% \mathrm{Al}_{2} \mathrm{O}_{3}$ and $\mathrm{CeO}_{2}$ were found to have negligible effect on the fracture toughness of Y-TZP throughout the sintering regime employed. The KIc of these samples was found to fluctuate between 4.67 $\mathrm{MPam}^{1 / 2}$ and $5.18 \mathrm{MPam}^{1 / 2}$, which implied that the tetragonal phase stability of Y-TZP was not disrupted. However, as the temperature increased above $1400^{\circ} \mathrm{C}$, an increasing KIc trend 


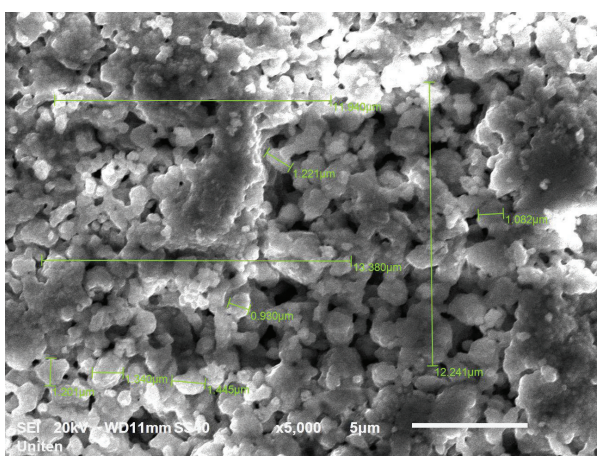

(a)

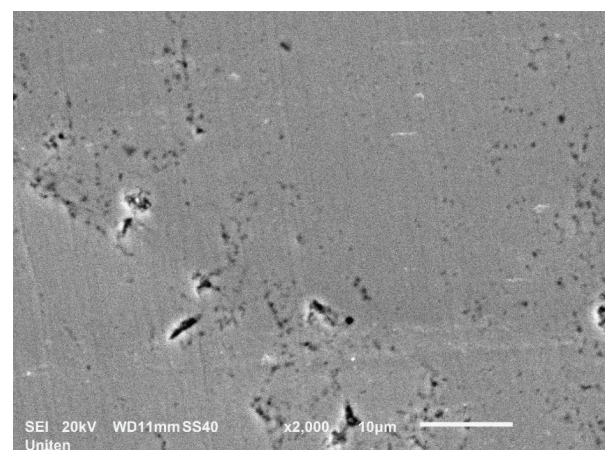

(b)

FIGURE 6: (a) SEM image showing lines intercepting on grain boundaries of sample at $1450^{\circ} \mathrm{C}$. (b) SEM image showing lines intercepting on grain boundaries of sample at $1250^{\circ} \mathrm{C}$.
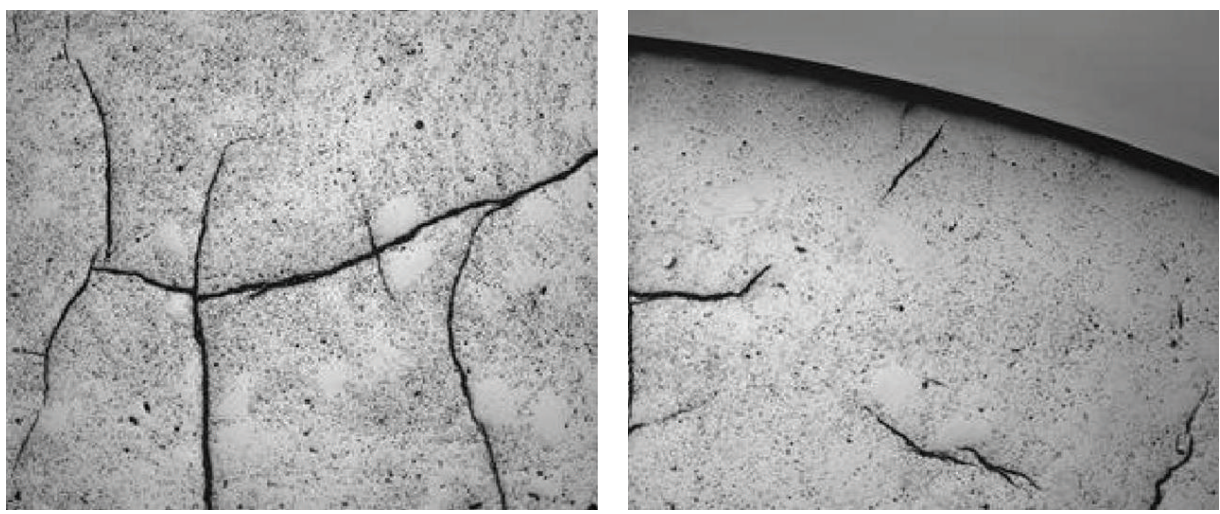

FiguRE 7: Effect of micro- and macrocracks on the surface of the $1 \mathrm{wt} \% \mathrm{Al}_{2} \mathrm{O}_{3}$ and $\mathrm{CeO}_{2}$-doped Y-TZP accompanying the $(t)$ to $(m)$ phase transformation upon cooling from sintering at $1450^{\circ} \mathrm{C}($ mag. $=\times 50)$.

was noted for both ceramics. In particular, the $1 \mathrm{wt} \% \mathrm{Al}_{2} \mathrm{O}_{3}$ and $\mathrm{CeO}_{2}$-doped Y-TZP exhibited a significant increase in the fracture toughness, from $4.8 \mathrm{MPam}^{1 / 2}$ at $1400^{\circ} \mathrm{C}$ to 7.1 $\mathrm{MPam}^{1 / 2}$ at $1450^{\circ} \mathrm{C}$.

\section{Conflict of Interests}

The authors declare that there is no conflict of interests regarding the publication of this paper.

\section{References}

[1] R. Stevens, "Introduction to Zirconia," in Zirconia and Zirconia Ceramics, pp. 28-43, Magnesium Elektron, 1986.

[2] L. Gakovic, "Ceramic center pin for compaction tooling and method for making same," U.S. Patent no. 7,214,046, 2007.

[3] P. Christel, A. Meunier, M. Heller, J. P. Torre, and C. N. Peille, "Mechanical properties and short-term in vivo evaluation of yttrium-oxide-partially-stabilized zirconia," Journal of Biomedical Materials Research, vol. 23, no. 1, pp. 45-61, 1989.

[4] J. Chevalier and L. Gremillard, "Zirconia as a Biomaterial," Comprehensive Biomaterials, vol. 1, pp. 95-108, 2011.

[5] T. Kokubo and N. Masahiro, "Hard tissue repairing material," European Patent No. EP1225927, 2002.
[6] L. Gremillard, J. Chevalier, T. Epicier, and G. Fantozzi, "Improving the durability of a biomedical-grade zirconia ceramic by the addition of silica," Journal of the American Ceramic Society, vol. 85, no. 2, pp. 401-407, 2002.

[7] S. Deville, J. Chevalier, and L. Gremillard, "Influence of surface finish and residual stresses on the ageing sensitivity of biomedical grade zirconia," Biomaterials, vol. 27, no. 10, pp. 2186-2192, 2006.

[8] A. Sundh and G. Sjögren, "Fracture resistance of all-ceramic zirconia bridges with differing phase stabilizers and quality of sintering," Dental Materials, vol. 22, no. 8, pp. 778-784, 2006.

[9] A. Dakskobler, P. Jevnikar, Č. Oblak, and T. Kosmač, "The processing-related fracture resistance and reliability of root dental posts made from Y-TZP," Journal of the European Ceramic Society, vol. 27, no. 2-3, pp. 1565-1570, 2007.

[10] Y. Wang and P. Xiao, "The phase stability and toughening effect of 3Y-TZP dispersed in the lanthanum zirconate ceramics," Materials Science and Engineering A, vol. 604, pp. 34-39, 2014.

[11] M. Nawa, K. Yamada, and N. Kurizoe, "Effect of the t-m transformation morphology and stress distribution around the crack path on the measured toughness of zirconia ceramics: a case study on Ce-TZP/alumina nanocomposite," Journal of the European Ceramic Society, vol. 33, no. 3, pp. 521-529, 2013.

[12] Z. Wei, P. Cheng, L. Ming, B. Mingmin, and R. Pinggen, "Effect of notch depth on fracture toughness of Y-TZP and determination of its actual value," Ceramics International, 2014. 
[13] Y. L. Zhang, X. J. Jin, Y. H. Rong, T. Y. Hsu, D. Y. Jiang, and J. L. Shi, "On the $\mathrm{t} \rightarrow \mathrm{m}$ martensitic transformation in Ce-Y-TZP ceramics," Acta Materialia, vol. 54, no. 5, pp. 1289-1295, 2006.

[14] I. Birkby and H. Hodgson, "Progress with zirconia ceramics," in Proceedings of the 3rd European Symposium on Engineering Ceramics, F. L. Riley, Ed., pp. 167-199, Elsevier Applied Science, 1991.

[15] C. F. Grain, "Phase relations in the $\mathrm{ZrO}_{2}-\mathrm{MgO}$ system," Journal of the American Ceramic Society, vol. 50, pp. 288-290, 1967.

[16] E. Marcella, N. Denis, B. W. Susie, M. P. Ast, M. W. Timothy, and E. P. Douglas, "Zirconia phase transformation, metal transfer, and surface roughness in retrieved ceramic composite femoral heads in total hip arthroplasty," The Journal of Arthroplasty, vol. 29, pp. 2219-2223, 2014.

[17] R. C. Garvie, R. H. Hannink, and R. T. Pascoe, "Ceramic steel?" Nature, vol. 258, no. 5537, pp. 703-704, 1975.

[18] K. Kobayashi, H. Kuwajima, and T. Masaki, "Phase change and mechanical properties of $\mathrm{ZrO}_{2}-\mathrm{Y}_{2} \mathrm{O}_{3}$ solid electrolyte after ageing," Solid State Ionics, vol. 3-4, pp. 489-493, 1981.

[19] L. Hallmann, P. Ulmer, E. Reusser, M. Louvel, and C. H. F. Hämmerle, "Effect of dopants and sintering temperature on microstructure and low temperature degradation of dental YTZP-zirconia," Journal of the European Ceramic Society, vol. 32, no. 16, pp. 4091-4104, 2012.

[20] M. Cattani-Lorente, S. S. Scherrer, S. Durual et al., "Effect of different surface treatments on the hydrothermal degradation of a 3Y-TZP ceramic for dental implants," Dental Materials, vol. 30, no. 10, pp. 1136-1146, 2014.

[21] S. Christian, R. Alexander, K. Christof, and K. Andreas, "Assessment of low-temperature degradation of Y-TZP ceramics based on Raman-spectroscopic analysis and hardness indentation," Journal of the European Ceramic Society, vol. 34, no. 16, pp. 43114319, 2014.

[22] S. Lawson, "Environmental degradation of zirconia ceramics," Journal of the European Ceramic Society, vol. 15, no. 6, pp. 485$502,1995$.

[23] L. Gremillard, J. Chevalier, T. Epicier, S. Deville, and G. Fantozzi, "Modeling the aging kinetics of zirconia ceramics," Journal of the European Ceramic Society, vol. 24, no. 13, pp. 3483-3489, 2004.

[24] S. Perko, A. Dakskobler, and T. Kosmac, "The densification and strength of porous Y-TZP materials with a bimodal particle size distribution for dental applications," Journal of the European Ceramic Society, vol. 32, no. 11, pp. 2633-2639, 2012.

[25] P. Kanellopoulos and C. Gill, "Hydrothermal ageing of yttriastabilised zirconia, sintered at $1300^{\circ} \mathrm{C}-1325^{\circ} \mathrm{C}$ : the effects of copper oxide doping and sintering time variations," Journal of Materials Science, vol. 37, no. 23, pp. 5075-5082, 2002.

[26] S. Ramesh, M. Amiriyan, S. Meenaloshini et al., "Densification behaviour and properties of manganese oxide doped Y-TZP ceramics," Ceramics International, vol. 37, no. 8, pp. 3583-3590, 2011.

[27] L. Winnubst, S. Ran, E. A. Speets, and D. H. A. Blank, "Analysis of reactions during sintering of $\mathrm{CuO}$-doped 3Y-TZP nanopowder composites," Journal of the European Ceramic Society, vol. 29, no. 12, pp. 2549-2557, 2009.

[28] M. Mazaheri, A. Simchi, and F. Golestani-Fard, "Densification and grain growth of nanocrystalline $3 \mathrm{Y}$-TZP during two-step sintering," Journal of the European Ceramic Society, vol. 28, no. 15, pp. 2933-2939, 2008.
[29] T. Xu, J. Vleugels, O. van der Biest, and P. Wang, "Fabrication and characterization of (Nd,y)-TZP ceramics from stabilizercoated nanopowder," Materials Letters, vol. 58, no. 26, pp. 33533357, 2004.

[30] T. Sato and M. Shimada, "Transformation of yttria -doped tetragonal $\mathrm{ZrO}_{2}$ polycrystals by annealing in water," Journal of the American Ceramic Society, vol. 68, no. 6, pp. 356-359, 1985.

[31] T. Sato, S. Ohtaki, T. Endo, and M. Shimada, "Transformation of yttria-doped tetragonal $\mathrm{ZrO}_{2}$ polycrystals by annealing under controlled humidity conditions," Journal of the American Ceramic Society, vol. 68, pp. 320-322, 1985.

[32] T. A. Egerton, E. J. Lawson, and P. W. Frost, "Stabilised zirconia," UK Patent Application GB 2181723 A, 1987.

[33] "Standard test method for dynamic young's modulus, shear modulus and poisson's ratio by impulse excitation of vibration," Annual Book of ASTM Standards ASTM E1876-97, 1998.

[34] R. C. Garvie and P. S. Nicholson, "Phase analysis in zirconia system," Journal of the American Ceramic Society, vol. 55, pp. 303-305, 1972.

[35] N. Kimura, S. Abe, J. Morishita, and H. Okamura, "Lowtemperature sintering of Y-TZP and Y-TZP- $\mathrm{Al}_{2} \mathrm{O}_{3}$ composites with transitional metal oxide additives," in Sintering '88, S. Somiya, Ed., vol. 2, pp. 1142-1148, Elsevier Applied Science, 1988.

[36] N. Kimura, S. Abe, Y. Hayashi, J. Morishita, and H. Okamura, "Sintering behavior and anti-degradation property of $\mathrm{MO}_{x}$ doped Y-TZP (M: Cu, Mn, Co, Ni, Zn)," Sprechsaal, vol. 122, no. 4, pp. 341-343, 1989.

[37] Y. Sakka, T. Ishii, T. S. Suzuki, K. Morita, and K. Hiraga, "Fabrication of high-strain rate superplastic yttria-doped zirconia polycrystals by adding manganese and aluminum oxides," Journal of the European Ceramic Society, vol. 24, no. 2, pp. 449453, 2004.

[38] S. Lawson, C. Gill, and G. P. Dransfield, “The effects of copper and iron oxide additions on the sintering and properties of $\mathrm{Y}$ TZP," Journal of Materials Science, vol. 30, no. 12, pp.3057-3060, 1995.

[39] X. Q. Liu and X. M. Chen, "Microstructures and mechanical properties of $\mathrm{Sr}_{2} \mathrm{Nb}_{2} \mathrm{O}_{7}$-toughened 3Y-TZP ceramics," Ceramics International, vol. 29, no. 6, pp. 635-640, 2003. 

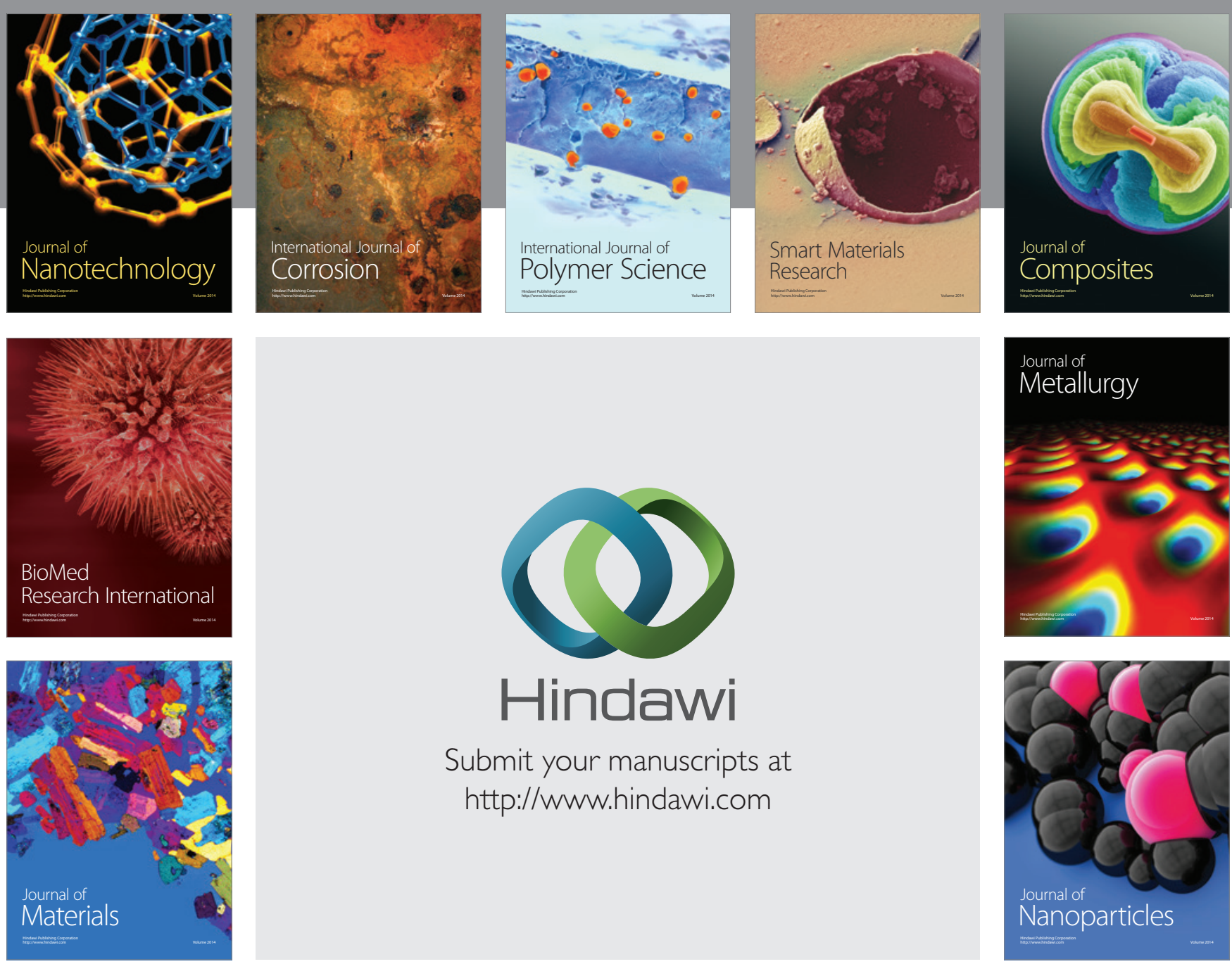

Submit your manuscripts at http://www.hindawi.com
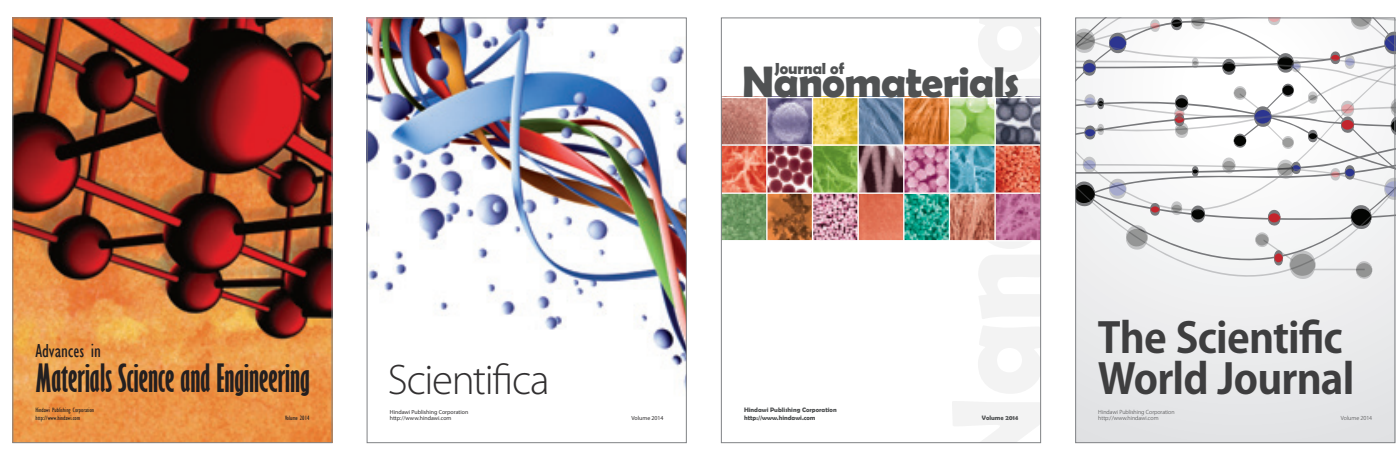

\section{The Scientific World Journal}
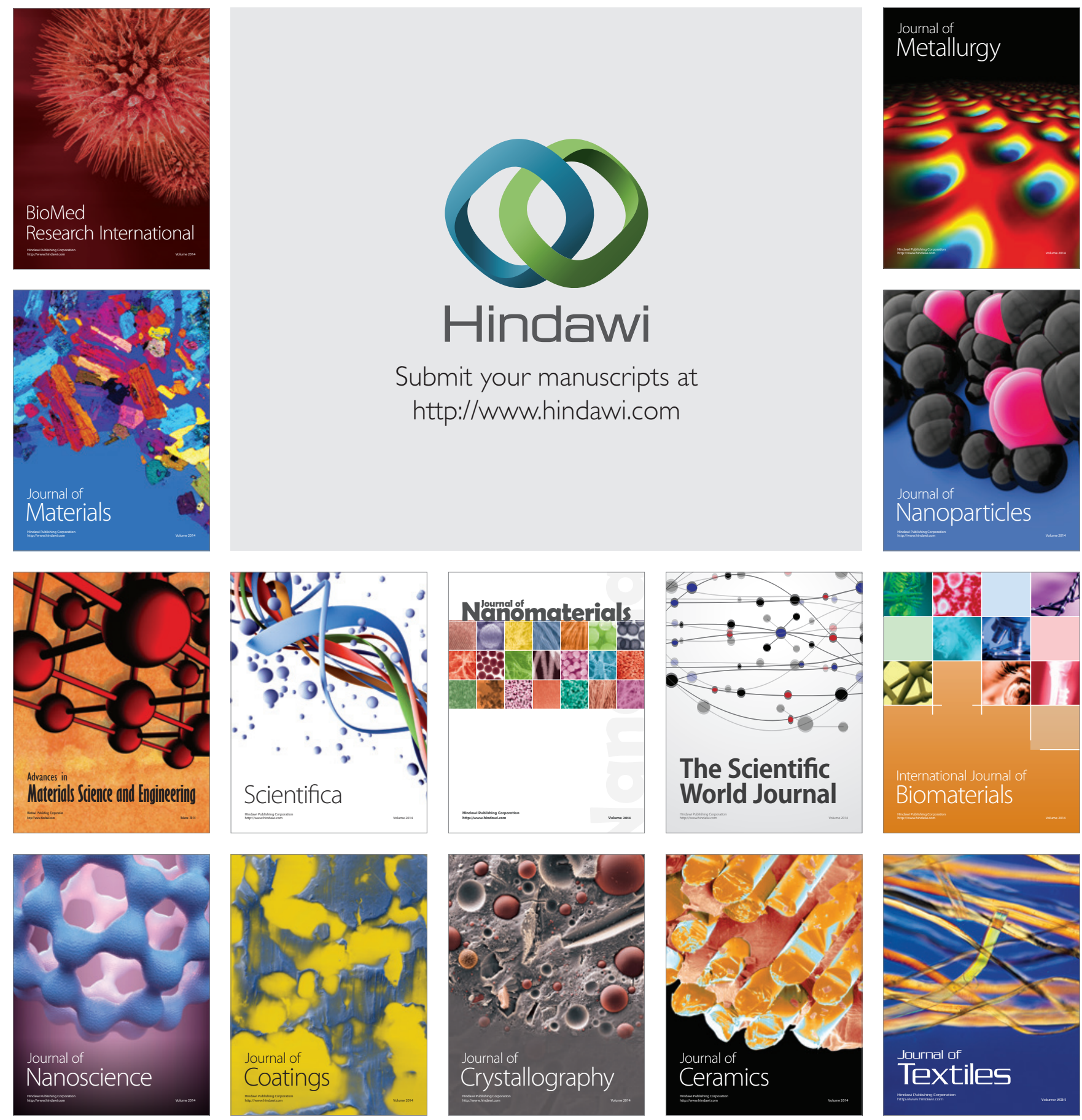